\title{
Teacher's Use of Power Bases as Perceived by ELT Students in Tertiary Education
}

\author{
Bahar $^{1}$, Oikurema Purwati², Slamet Setiawan ${ }^{3}$ \\ ${ }^{1}$ Doctoral Program of Language and Literature Education, Surabaya State University, Indonesia, Faculty of \\ Social Economic, English Literature Department, Fajar University Makassar, Indonesia \\ ${ }^{2,3}$ Postgraduate School, Surabaya State University, Indonesia \\ bahar.17070956004@mhs.unesa.ac.id
}

\begin{abstract}
This study attempts to examine Power relations perceived by students in classroom interaction in tertiary education Context. Good classroom interaction is perceived as one when all the students are actively engaged with what is happening in the classroom. This means that students are accounted for to be responsible for their own learning. A mixed-method was carried out by exerting questionnaires and focused interviews. The perception questionnaires were given to 40 students majoring in English Literature at Fajar University of Makassar on the Students' perception toward power in the classroom context. In order to have more elaborated information about power relations in the classroom context, the researcher employed focused interviews with 10 students who were chosen randomly. The findings suggest that there are several things influenced power and solidarity in EFL classroom interaction, the majority of the students perceived that their teacher is a dominant figure in the classroom. Nonetheless, the students do recognize that when teachers are being dominant; it means they want everyone to equally participate in the class. Students also affirm that confidence is needed to be able to participate in classroom activities and that support from their classmates is influential to some extent.
\end{abstract}

Keywords

perception; power; classroom interaction

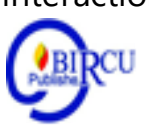

\section{Introduction}

Classroom interaction provides students with opportunities to an intensive and structured interaction among them (Wang et. al 2015). There are several key features that contribute to the successful learning outcome; one of them is a good classroom interaction. Good classroom interaction is perceived as when all the students are actively engaged with what is happening in the classroom. When students are actively engaged, they will be responsible for their own learning. The concept of so-called good classroom interaction is varied based upon the objective of the study itself. Yet it can simplify that a good classroom interaction has a big contribution to the learning outcome. Umbach (2007) stated that students' interaction determines their development and success. When one talks about classroom interaction, it may include classroom management, student-teacher relation and so on, in this research; the researcher would like to shed some light on power and solidarity in relation to classroom interaction itself. Mchoul (Thornborrow 2002:111) research revealed that the talking in the classroom is dominated by the teacher in monologic form, therefore, the possibility for students to take equal turns is reduced. This phenomenon is that teachers do most of the talking and hold the power in the classroom and students are merely there to be passive and less likely to engage in the classroom that hinders them to participate more as they should. Teacher performance is the implementation of a plan that has been prepared through planning good learning activities that is by completing learning tools in the form of 
syllabus and learning implementation plans (RPP) instead planning poor learning activities if the teacher does not prepare learning tools in the form of syllabus and lesson plans. Implementation of performance is carried out by human resources who have the ability, competence, motivation, and interests. How madrasas respect and treat their human resources will influence their attitudes and behavior in carrying out performance. (Saragih, 2019)

Moreover, Dangel and Durden (2010) claim that teacher talk is a powerful classroom tool to convey and construct meaning. On the other hand, Sequeiros (1997) noted that both teachers and students consider solidarity as a value that entails closeness with others. While power sometimes considered a negative thing, solidarity is perceived more positively among people. Moreover, Ramos (2004) stated that to recognize the power in the educational context has been studied by many authors who have evidenced its importance not only in a distinct community but also in any place in which interaction occurs.

\section{Theoretical Framework}

\subsection{The Notion of Power}

Power is a word in English that related to dominance, superiority, etc. There are different ways of projecting power that is known to the human being. In primitive society for example, power is shown through physical coercion. Since humans back then are incapable of using their logic, the ones with the bigger body are justified to rule others. It is the power and superior position is that distinguish the place that people hold in certain cultures and communities.

Power is one of the major concepts used in study of language. Jones (ps tectalk) argues that power does not exist by itself, it is the people that are responsible for such terms to appear in communication. Ramos (2004) stated that power is important, that it exists every time interaction occurs. Power is the degree to which one interlocutor is able to control the behavior of others (Sterling, 2000). The basis of power relationships are things such as physical strength, wealth, age, sex, also in some institutional role such as in the army, within the family etc. such relation as older than, richer than, stronger than, or any other kind of superiority is all symmetrical relationship.

\subsection{Power in the Classroom}

To give meaning to power and solidarity is considered simple, as many scholars have tried and succeeded in defining both. Brown and Gilman (1996) claim that in every conversation, there is always one person that holds power to control the talk and also the behavior of other persons meaning that there is no way that both speakers have the same level of power. Ramos (2004) stated that power is important, that it exists every time interaction occurs. Power is the degree to which one speaker is able to control the behavior of others (Sterling, 2000).

The basis of power relationships are things such as physical strength, wealth, age, sex, also in some institutional role such as in the army, education institution, within the family, etc. such relation as older than, richer than, stronger than, or any other kind of superiority is all symmetrical relationship. In contrast to power with the asymmetrical relationship, solidarity is all about the symmetrical relationship in which everyone involved is assumed to have a similar background, for example, the similarity in social class (Tannen, 1993). Thomas (1998) backed that theory by noting that the bases of the concept of solidarity are salient sameness. For instance, students in the same class are likely to be in a similar state of knowledge on subjects. 
In the classroom context, the form of power in interaction has to be taken into consideration, since the institutional setting influences the interactional context (Thornborrow 2002). This indicates that the teacher is seen as someone that holds power in the class that came with her institutional role.

\section{Research Method}

This research employed a descriptive study that is defined as "closely examine a phenomenon since the beginning that allows the researcher to carefully observe, describe, and analyze the situation extensively (Tobin, 2010). In this study, the phenomenon under scrutiny is students' perception of the power relation in an EFL classroom in Fajar University, Makassar.

\subsection{Participants}

The participants of the present study included 40 students of Fajar University with a diverse level of English and background. They were majoring in English language study sitting in the 1 st to 5 th semester. Among the participants, 29 were female students and 11 were male students. One female TEFL teacher participated in the study. She held a postgraduate degree in English language study with a high level of English proficiency.

Moreover, in order to get more elaborated data, the researcher employ focused interview to 10 students, 5 males, and 5 females. The samples for both were taken purposively. In this sense, the participants were being examined in their natural setting and were not asked to change anything at all. Both the data from the questionnaire and interview assisted in providing an in-depth description of power relations in tertiary education not only from the researcher's point of view but also from the participants' perspective.

\subsection{Data Collection Instrument}

This research adopts two types of data collection instrument which is a questionnaire and a focused interview. A questionnaire was employed to investigate the perception of the students of the English department at Fajar University, Makassar, Indonesia. The questionnaire inquired are 20 items in this 5-point Likert scale questionnaire that will unveil students' perception toward power relations in classroom interaction. Upon the distribution of the questionnaire, the researcher explains the student's every base of power as the center of the questionnaire. And then after that, 10 students were chosen randomly by regarding their gender, the researcher chose 5 female and 5 male students. The interview is still about the bases of power with open questions with semi-structured type.

\subsection{Research Procedure}

A perception questionnaire was created with the basis of power relations. The students are asked to give their responses to the 20 items in the questionnaire based on their own opinions toward power relations in an EFL classroom interaction in the tertiary education context. Data gained from the students' responses were then analysed manually using frequency formula.

The data were taken in August 2019. During the administration of the questionnaire, the researcher explains to the students the concept of power and the purpose of the questionnaire. The researcher also re-read the questionnaire and makes sure that the students understood each item in the questionnaire. Students were asked to rate each item based on a scale from Never, Seldom, Sometimes, Often, and Always. Then the overall result was computed. Moreover, 5 male students and 5 female students were enrolled in the interview which is 
focusing on elaborating students' views on power relations in the EFL classroom of tertiary education.

\section{Discussion}

Students' perception of power relations is being examined through this research. The perceptional questionnaire was successfully administered to the students to gauge students' perception of power relations in an EFL classroom interaction of higher education. The Questionnaire consisted of 20 questions in which were projecting power relations in the EFL classroom interaction. The analysis of the data was presented as follows:

\subsection{Students' View of Teachers' Use of Coercive Power}

The data from the questionnaire revealed that this type of power is the least type that students viewed being used by the teacher. Coercive power signified as a thought of punishment that comes when a certain influence (from the one holds the power) is not being met. When teachers used this type of power, it usually means that to a certain degree students are forced to comply with the teachers' request bearing in mind that the teacher will do something harmful if they did not. Here is the data of the questionnaire regarding coercive power

Table 1: Percentage for coercive power

\begin{tabular}{|c|c|c|c|c|c|c|}
\hline \multicolumn{7}{|c|}{ Coercive Power } \\
\hline Item Number & 5 & 4 & 3 & 2 & 1 & TOTAL \\
\hline 1 & $0 \%$ & $0 \%$ & $0 \%$ & $5 \%$ & $95 \%$ & $100 \%$ \\
\hline 2 & $0 \%$ & $0 \%$ & $0 \%$ & $0 \%$ & $100 \%$ & $100 \%$ \\
\hline 3 & $0 \%$ & $0 \%$ & $0 \%$ & $20 \%$ & $80 \%$ & $100 \%$ \\
\hline 4 & $0 \%$ & $0 \%$ & $0 \%$ & $40 \%$ & $60 \%$ & $100 \%$ \\
\hline
\end{tabular}

The data revealed that their language teacher is rarely projecting her power position in the classroom associated with coercive power. The percentage of the use of coercive power is mostly negative meaning that the students perceived their teacher to not use this type of power in the classroom. As in item number 2 inquired that the teacher uses physical abuse when the students misbehave in the class, all students' response was strongly disagreed. Therefore, the feature of the common use of coercive power such as facing a consequence, or fear of being mistreated or miss-handled is not a threat in their language class. Coercive power is also related to the students' understanding that a non-conformance attitude toward the teachers' demand will produce a negative consequence. Students admit in their interview that their language class is a set out as a harmless environment where being afraid of punishment is out of the picture. Yet one female interviewee thinks that coercive power is sometimes needed in a situation where a teacher is hard is necessary.

Student A: my lecturer never hit students, not yell also, but sometimes I wish she can hit students if they do not want to be quiet during the class because their voice interrupts other students to learn. 
Meanwhile, the other students subjected to the interview affirmed that their teacher does not utilize any form of the physical or oral form of abuse and support that the teacher does not use this kind of power in her English class to the students.

\subsection{Students' view of teachers' use of Reward power}

The idea of reward power is based on the students' perception that if they meet a certain expectation from their teacher, then they will get a reward of positive reinforcement. Most scholars argue that in the classroom setting, the desired price given by the teacher is a good grade or words of confirmation in the class or can also be something else that is seen as a reward. Here is the students' perception of the teacher's use of reward power.

Table 2: Percentage for reward power

\begin{tabular}{|l|l|l|l|l|l|l|}
\hline \multicolumn{7}{|l|}{ Reward Power } \\
\hline $\begin{array}{l}\text { Item } \\
\text { Number }\end{array}$ & 5 & 4 & 3 & 2 & 1 & TOTAL \\
\hline 5 & $0 \%$ & $55 \%$ & $35 \%$ & $10 \%$ & $0 \%$ & $100 \%$ \\
\hline 6 & $35 \%$ & $40 \%$ & $25 \%$ & $0 \%$ & $0 \%$ & $100 \%$ \\
\hline 7 & $30 \%$ & $45 \%$ & $20 \%$ & $5 \%$ & $0 \%$ & $100 \%$ \\
\hline 8 & $35 \%$ & $45 \%$ & $20 \%$ & $0 \%$ & $0 \%$ & $100 \%$ \\
\hline
\end{tabular}

The data from the questionnaire revealed that students are in the position of agreeing to the statement saying that their teacher often gives them some form of reward when they complete a task, as the item number 6 . It can be seen from Table 2 that $75 \%$ students agreed to this statement. Moreover, they also admit to a reduced task to do when the teacher feels satisfied with what they did in the class as presented in item 7 . And the students also contend that words of affirmation and encouragement were also given by the teacher when the students answer her question correctly as in item number 8 . The students from the interview affirmed similar information, that they can negotiate how many tasks to do, and that the number of tasks can be reduced when the teacher felt they have done better in their previous task and so on. Based on the interview, the students admit that the lecturer often uses reward power in the classroom.

Student B: my teacher usually praise us when we do something right in the classroom. She often encourages us to answer questions or participate in the discussion.

Students 'view of teachers' use of legitimate power

Legitimate power is actually viewed as an initial right that the teacher has to enforce his or her power on the student. This power actually means the control teacher has on the regular, day-to-day job such as determining class time, units to study, organize classroom interaction, and so on. The data show a high frequency in this use of power. A teacher does to a high extent exercise her legitimate power in the class. The data from the questionnaire can be seen below; 
Table 3: Percentage for Legitimate Power

\begin{tabular}{|c|c|c|c|c|c|c|}
\hline \multicolumn{7}{|c|}{ Legitimate Power } \\
\hline \multicolumn{7}{|c|}{ Item } \\
\hline \multicolumn{7}{|l|}{ Number } \\
\hline 9 & $80 \%$ & $20 \%$ & $0 \%$ & $0 \%$ & $0 \%$ & $100 \%$ \\
\hline 10 & $75 \%$ & $20 \%$ & $5 \%$ & $0 \%$ & $0 \%$ & $100 \%$ \\
\hline 11 & $55 \%$ & $45 \%$ & $0 \%$ & $0 \%$ & $0 \%$ & $100 \%$ \\
\hline 12 & $40 \%$ & $60 \%$ & $0 \%$ & $0 \%$ & $0 \%$ & $100 \%$ \\
\hline
\end{tabular}

If we were to look closely at 4 items representing legitimate power, the percentage is in the midst of strongly agree to agree which can be interpreted that this power is highly used in the teacher's teaching management. This is similar to the notion of power itself by Brown and Gilman (1996) that claims in every conversation, there is always one person that holds power to control the talk and also the behavior of other person meaning that there is no way that both speakers have the same level of power. In the classroom situation, the teacher is the one holding more power than the students and it is projected in her use of legitimate power. As in item number 9, all students are in agreement upon the statement that their teacher controls what subject they need to study and what method to use. Item number 10 also has the highest percentage; the students affirmed that the teacher sometimes appoints which students of her choosing to answer the question raised during classroom interaction. According to the students in the interview, the teacher usually depends on her subject contract in deciding what subjects should be learned. The teacher also projects her legitimate power by regulating turntaking during the classroom in two ways; asking students to answer her question voluntarily and point a student to answer her question.

Student C: our teacher tells us the material we are going to study usually the day before when we confirmed her schedule for our class. She also often change her teaching method as she sees fits.

\subsection{Students' view of teachers' use of Referent power}

The basis of referent power is the way students identify the teacher. Identify in this terms means attraction (in a teacher-student way), the students as the ones hold the less power in the classroom please the one that holds the power which in this case the teacher. The study acknowledges that the students do want to please their teacher as the item number 13 reports and are doing it in their own way. Mostly they do such by being active in the class and answering the teacher's question. The data for the use of referent power base are bellow;

Table 4: Percentage for referent power

\begin{tabular}{|l|l|l|l|l|l|l|}
\hline \multicolumn{2}{|l|}{ Referent Power } \\
\hline $\begin{array}{l}\text { Item } \\
\text { Number }\end{array}$ & 5 & 4 & 3 & 2 & 1 & TOTAL \\
\hline 13 & $25 \%$ & $70 \%$ & $5 \%$ & $0 \%$ & $0 \%$ & $100 \%$ \\
\hline 14 & $10 \%$ & $75 \%$ & $15 \%$ & $0 \%$ & $0 \%$ & $100 \%$ \\
\hline
\end{tabular}




\begin{tabular}{|l|l|l|l|l|l|l|}
\hline 15 & $15 \%$ & $85 \%$ & $0 \%$ & $0 \%$ & $0 \%$ & $100 \%$ \\
\hline 16 & $10 \%$ & $78 \%$ & $13 \%$ & $0 \%$ & $0 \%$ & $100 \%$ \\
\hline
\end{tabular}

The data showed that the students look up to their teacher and respected her in a way that behaving badly is something they avoid as shown in item number 15 . The interviewed students believed that being a student means one acknowledges that a teacher is a person who is in a higher place than them, in terms of age, knowledge, and position, therefore, reverting to the teacher is something they must do.

Student D: I I think she is a good teacher, she explains materials very clear that make us very informed, and the class situation also good,

Moreover, the other student we interview also told us that the lecture is very cheerful and it makes the classroom relaxed

Student E: she likes to smile and she sometimes makes a joke, so we are happy in the class Students' view of teachers' use of Expert power

Expert power is viewed as the students' perception that the teacher is the most knowledgeable and resourceful in the classroom. This base of power is actually the ground of power relations in most classroom interactions. The students in their mind during the learning process perceived that the teacher is someone competent in her subject matter. The stronger this perception is will result in the stronger the teacher's expert power.

Table 5: Percentage for Expert Power

\begin{tabular}{|c|c|c|c|c|c|c|}
\hline \multicolumn{7}{|c|}{ Expert Power } \\
\hline $\begin{array}{l}\text { Item } \\
\text { Number }\end{array}$ & 5 & 4 & 3 & 2 & 1 & TOTAL \\
\hline 17 & $85 \%$ & $15 \%$ & $0 \%$ & $0 \%$ & $0 \%$ & $100 \%$ \\
\hline 18 & $95 \%$ & $5 \%$ & $0 \%$ & $0 \%$ & $0 \%$ & $100 \%$ \\
\hline 19 & $75 \%$ & $25 \%$ & $0 \%$ & $0 \%$ & $0 \%$ & $100 \%$ \\
\hline 20 & $60 \%$ & $40 \%$ & $0 \%$ & $0 \%$ & $0 \%$ & $100 \%$ \\
\hline
\end{tabular}

The study revealed that students believed that their teacher is an expert in her subject matter. They address having no doubts that the teacher will be able to answer their inquiry inside the classroom or even outside the classroom as long as it is still about her subject matter as presented in item 18 where $95 \%$ strongly agree to the statement and the other 5\% was agreed. Moreover, a similar answer was also projected by item numbers 17 and 1 that both confirmed the students' confidence toward their teacher's expertise in expert power. The data from the interview is also showing similar agreement;

Student F: the teacher can always explain again if we did not understand or when we have question, she does not delay our questions 
Student G: I think she knows what she is teaching because she teach good and she make us understand

It can be presumed from the findings that the teacher's actual power in the classroom does not entirely depend on the teacher herself but also from how the students' perceived that power upon her. In line with the result of the present study, Chesebro and Martin (2010) find in their study that requests or expectations offered by the teacher may have various meanings for students, depending on the way in which these messages are framed. In turn, these frames may influence various student perceptions and behaviors toward the teacher themselves.

This is similar to the research conducted by Finn (2011) saying that results of his study revealed that teacher use of reward, expert and referent power is positively associated with perceived teacher's understanding and negatively related to perceived teacher misunderstanding, whereas teacher use of legitimate and coercive power is negatively related to perceived teacher understanding and positively associated with perceived teacher misunderstanding.

\section{Conclusion}

This study identified the bases of power the teacher use in an EFL classroom of tertiary education from the students' point of view. The result showed that the teacher uses varied power bases in the class, yet coercive power is the least power utilized by the teacher. Both the study from the questionnaire and interview are similar in terms of the teacher's use of power base in the classroom.

It is recommended that the teacher explore more about the bases of power and extend that power to the students as well. The teacher should also try elevating the student's use of different power bases so that new experiences in the classroom can be built. Students also should be able to participate in the use of expert power, so that the power used by the teacher will not create a discrepancy. Nonetheless, there are still many things that cannot be answered through this research in regards to the power dynamics in the classroom. And that the gap can be an opportunity for a further researcher.

\section{References}

Brown, Roger, and Albert Gilman. (1960). The Pronouns of Power and Solidarity. Style in Language Cambridge, Mass: MIT Press, T. A. Sebeok, 253-276.

Coulthard, R. M. (1985). An introduction to discourse analysis. London: Longman.

Chesebro, J. L., \& Martin, M. M. (2010 ). Message framing in the classroom: The relationship between message frames and student perceptions of instructor power. Communication Research Reports, 27(2), 159-170.

Dangel, J.R. and T.R. Durden. (2010). The nature of teacher talk during small group activities.

Finn, A. N. (2012). Teacher use of prosaically and antisocial power bases and students' perceived instructor understanding and misunderstanding in the college classroom. Communication Education, 61(1), 67-79.

Ramos, B. (2004). Power Relation in the EFL class through oral interaction (Master's thesis),Universidad Detrital Francisco José de Caldas, Bogotá.

Sterling, Polly. Identity in Language: An Exploration into the Social Implications of Linguistic Variation. Texas: A\&M University 
Hurt, H.T.,Scott. D\&McCroskey,J.C. (1978). Communication in the classroom. Reading MA: Addition-Wesley.

Mat Zin, S., N.F.H. Nik Jaafar, N.E. Ngah, R. Ismail, N. Ibrahim, K. Jusoff and A. Salleh. (2011). Ingratiation and the use of power in Malaysian secondary Schools, World Applied Sciences Journal, 12: 10-14.

Mendez, Tatiana. (2012) Exploring Students' Power and Solidarity Relation in an EFL Classroom. Issues in Teachers' Profesional Development, Vol. 4, Issue 1, page 173185.

McKeachie, W. J. (1990)."Research on College Teaching: The Historical Background." Journal of Educational Psychology, 82 189-200.

Petress, K.( 2006) An operational definition of class participation, College Student Journal, 40, 821823. (ASO)

Saragih, S. (2019). The Relation between the Empowerment of Teacher's Meeting and Achievement Motivation on Teacher Performances in MTsN 3 (Islamic Junior High School 3) Simalungun. Budapest International Research and Critics in Linguistics and Education (BirLE) Journal. p. 115-114.

Sequeiros, L. (1997). Educar para la Solidaridad. Barcelona: Octaedr

Smith, D. G. (1977) "College Classroom Interactions and Critical Thinking." Journal of Educational Psychology, 69 180-90.

Tannen, D. (1996). Researching gender-related patterns in classroom discourse. TESOL Quarterly,. 30(2), 341-344. 